\title{
IN VITRO CHARACTERIZATION OF BACTERIAL ENDOPHYTES FROM TOMATO (SOLANUM LYCOPERSICUM L.) FOR PHYTOBENEFICIAL TRAITS
}

\author{
IQBAL, S. ${ }^{1}-$ HAMEED, S. $^{1}-$ SHAHID, M. ${ }^{2,1^{*}}-$ HUSSAIN, K. ${ }^{1,3}-$ AHMAD, N. $^{1,4}-$ NiAZ, M. ${ }^{5}$ \\ ${ }^{I}$ Microbial Physiology Lab, National Institute for Biotechnology \& Genetic Engineering \\ (NIBGE), \\ P.O. Box 577, Jhang Road, Faisalabad, Pakistan \\ ${ }^{2}$ Department of Bioinformatics and Biotechnology, Government College University, \\ Faisalabad-38000, Pakistan \\ ${ }^{3}$ Department of Botany, Ghazi University \\ Dera Ghazi Khan, Pakistan \\ ${ }^{4}$ Department of Chemistry, Faisalabad Campus, University of Education, \\ Faisalabad-38000, Pakistan \\ ${ }^{5}$ Department of Botany, Government College University, \\ Faisalabad-38000, Pakistan \\ *Corresponding author: \\ e-mail: shahidmpg@yahoo.com; phone: +92-300-7919822 \\ (Received 28 ${ }^{\text {th }}$ Aug 2017; accepted $18^{\text {th }}$ Dec 2017)
}

\begin{abstract}
Bacterial endophytes, with plant beneficial traits, are being routinely isolated and investigated to address environmental impacts and low nutrient use efficiency of chemical fertilizers. The current study was framed with a hypothesis that local cultivar of tomato (Solanum lycopersicum L. cv. Nagina) harbors multi-trait endophytes with plant-beneficial attributes. From a collection of purified root endophytes, only two isolates viz. NgE3 and NgE4 with desired PGP traits were identified as Bacillus subtilis and Paenibacillus sp., respectively on the basis of 16S rRNA gene sequence analysis. Both the strains exhibited substantial nitrogenase activity, tricalcium phosphate-solubilizing ability and were positive for 1-aminocyclopropnae-1-carboxylate (ACC) deaminase synthesis. A considerable quantity of Indole-3-acetic acid was measured only in the culture supernatant of Paenibacillus strain NgE4, while Nacyl homoserine lactones (AHLs) production was found positive in Bacillus subtilis $\mathrm{NgE3}$. Both the strains also revealed considerable antifungal activity (> 70\%) against at least 3 out 5 fungal pathogens tested. The root colonization potential of Bacillus and Paenibacillus strains was confirmed by localizing the strains in the tomato root cortical cells as endophytes through transmission electron microscopy. Keeping in view very limited research reported on bacterial endophytes in Pakistan, both phytobeneficial strains are potential resources as bio-inoculants for the tomato to design greenhouse and field experiments.
\end{abstract}

Keywords: isolation, plant-beneficial traits, $16 \mathrm{~S}$ rRNA, transmission electron microscopy, antifungal activity

\section{Introduction}

Maintenance of agricultural productivity for ever-increasing world population along with preservation of natural resources has become a major challenge in both developed and developing countries (Singh, 2017). Up to now, the farmer's strategy to increase crop productivity was totally based on the use of chemical fertilizer inputs; however, increasing the fertilizer inputs is no more boosting the agricultural yields in recent 
decades due to their low nutrient use efficiency (Yousaf et al., 2017). Therefore, this prompts the need to characterize the plant beneficial bacteria for their ultimate field inoculation as nutrient supplying agents (Hanif et al., 2015; Pii et al., 2015; Akram et al., 2016; Mahmood et al., 2017). Such beneficial bacterial agents, often known as plant growth-promoting rhizobacteria (PGPRs), establish a strong association with rhizosphere, the soil adhering to the root surfaces (Kloepper et al., 1989). They are also found in the direct attachment to the root surfaces as rhizoplanic bacteria, and tend to pierce root epidermis and cortex as endophytes (Sylvia et al., 2005; Shaid et al., 2015).

With the advent of advanced molecular techniques, it is now possible to sequence the genomes of both bacterial and fungal endophytes without isolation and purification on culture media. Thus, the more advanced definition of endophytes is the set of microbial genomes inside the plant organs (Bulgarelli et al., 2013). Endophytes are of three types depending upon plant inhabiting life strategies (Hardoim et al., 2008). Obligate endophytes transmit via seeds and are unable thrive outside the plants. For instance, Xylella fastidiosa is found in plant tissues as obligate endophyte and is capable of persisting inside the plant for long period of time (Hardoim et al., 2008). Xylella fastidiosa transmit through insect vectors. Facultative endophytes live freely in soil and cause infection and colonization as opportunity arrives (Hardoim et al., 2008); most endophytes known for plant growth promotion belong to this class, e.g. Pseudomonas fluorescence and Azospirillum brasilense. These endophytes enter in plants through cracks in lateral roots or wounds caused by nematodes or plant pathogens (Rosenblueth and Martinez-Romero, 2006). Many other rhizosphere competent bacterial genera are considered as endophytes at some stage of their life cycle. The third category, known as passive endophytes, is not competitive in terms of root colonization and plant growth promotion. Even though they lack the active machinery of plant infection and colonization, transmission via plant roots may occur as result of stochastic events (Verma et al., 2004; Rosenblueth and Martínez-Romero, 2006; Hardoim et al., 2008). After infection and transmission to roots, endophytes can exist both inter- and intracellularly (Hurek et al., 1994; Zakria et al., 2007). A variety of plant species bear bacterial endophytes as part of their root microbiome, with some being known to improve plant growth and productivity by exploiting a variety of mechanisms (Gaiero et al., 2013). Endophytic bacteria are also known to tolerate salt-stress and induce salinity tolerance mechanisms in plants (Damodaran et al., 2014; Yaish et al., 2015). Despite the extensive research on bacterial root endophytes to apply as inoculants for plant growth promotion (Thakore, 2006), a limited understanding exists about the drivers of endophytic communities and mechanisms involved for the success of inoculation in crop productivity. Bacterial endophytes, by synthesizing ACC deaminase enzyme, reduce ethylene concentration and help plants to thrive in adverse environmental conditions. Bacterial endophytes have also been described to produce phytohormones like indole-3-acetic acid (Hardoim et al., 2008). Moreover, different types of AHLs (C6, $\mathrm{C} 8, \mathrm{C} 10$, oxo-C12, 3-oxo-C6 etc.) are known to produce by endophytes for signal transduction during the association. These AHLs participate in plant signaling pathways to sense ecological dynamics (Hartmann et al., 2014).

In vitro characterization of endophytes for plant beneficial properties is the first key step towards the selection of potential bacterial inoculants and investigation of the mechanism involved in phytostimulation (Jasim et al., 2014). So far, most of the studies on bacterial endophytes from tomato were either aimed at their characterization for PGP traits (Amaresan et al., 2012) or biocontrol of phytopathogens (Munif et al., 2013; 
Upreti and Thomas, 2015). The present piece of work is conducted to target multi-trait bacterial endophytes from a local tomato cultivar bearing not only PGP characteristics but also antagonism against plant pathogenic fungi. The study will go a long way in the elucidation of the role of these endophytes for vigor and yield improvement of the tomato crop. Furthermore, the baseline information of these endophytic bacterial associations of tomato will steer to more comprehensive studies in terms of exploring the biochemical and genetic basis of this association.

\section{Materials and methods}

\section{Isolation and morphological studies}

Tomato plants (cv. Nagina), grown at experimental field of Nuclear Institute of Agriculture and Biology (NIAB, 31 ${ }^{\circ} 23^{\prime} 42.13$ N, 731'37.24 E), Faisalabad, Pakistan were uprooted followed by excision of aerial parts with sterilized a knife for isolation of bacteria from endosphere portion of the plant. This cultivar is considered as salt tolerant genotype (Amjad et al., 2014a; 2014b), and thus, selected for isolation of root endophytes. The samples were carried in sterilized polythene bags $(25 \times 30 \mathrm{~cm})$ to the Microbial Physiology Laboratory, National Institute for Biotechnology and Genetic Engineering (NIBGE), Faisalabad, Pakistan. Root portions were subjected to washing with tap water followed by sterile distilled water to detach adhered soil. Root surfaces were disinfected by dipping in ethanol (70\%) for $1 \mathrm{~min}$ and sodium hypochlorite $(5 \%$ [w/v]) for another $10 \mathrm{~min}$, followed by 5-6 washings with sterilized distilled water. For bacterial isolation, $1 \mathrm{~g}$ of macerated roots were put in $9 \mathrm{ml}$ of saline solution $(0.85 \%$ $(\mathrm{w} / \mathrm{v}) \mathrm{NaCl}$ ) by serial dilution technique described by Somasegaran and Hoben (1994). Aliquots $(100 \mu \mathrm{l})$ from two dilutions $\left(10^{-4}\right.$ and $\left.10^{-6}\right)$ were spread on Luria-Bertani (LB) agar plates using a sterilized glass spreader, followed by $48 \mathrm{~h}$ incubation in a microbial incubator (Memmert, Germany) preset at $28 \pm 2$. Bacterial colonies were selected on the basis of prolific growth and colony morphology and purified through repeated streaking. The purified isolated were maintained at LB-agar plates to carry out further experiments. Five copies of each purified isolate were preserved in $20 \%(\mathrm{v} / \mathrm{v})$ glycerol at $-80{ }^{\circ} \mathrm{C}$. Various morphological characteristics like the colony and cell morphology, motility and Gram's reactions were studied under the light microscope as described by Vincent (1970).

\section{Nitrogen fixation}

Nitrogen fixation ability of isolates ( $\mathrm{NgE3}$ and $\mathrm{NgE} 4$ ) was assessed by acetylene reduction assay (ARA) using GC-FID as described by Hardy et al. (1968). The purified isolates were individually inoculated into $30 \mathrm{ml}$ semisolid nitrogen free malate (NFM) medium (In 11 distilled water: $5 \mathrm{~g} \mathrm{l}^{-1}$ malic acid, $0.5 \mathrm{~g} \mathrm{l}^{-1} \mathrm{~K} 2 \mathrm{HPO} 4,0.2 \mathrm{~g} \mathrm{l}^{-1}$ MgSO4.7H2O, $0.02 \mathrm{~g} \mathrm{l}^{-1} \mathrm{CaCl} 2,0.1 \mathrm{~g} \mathrm{l}^{-1} \mathrm{NaCl}, 0.002 \mathrm{~g} \mathrm{l}^{-1} \mathrm{NaMoO} 4.2 \mathrm{H} 2 \mathrm{O}, 5 \mathrm{ml} \mathrm{0.5 \%}$ (w/v) bromothymol blue (BTB), $10 \mu \mathrm{g}$ biotin, $0.2 \%$ (w/v) agar, $\mathrm{pH} 7$ was adjusted with $\mathrm{KOH}$ (Okon et al., 1977), in Erlenmeyer flasks $(100 \mathrm{ml})$ and allowed to grow in an orbital shaker (150 rpm, Gallenhamp, UK) at $28 \pm 2{ }^{\circ} \mathrm{C}$ for $72 \mathrm{~h}$. A well-grown culture $(4 \mathrm{ml})$ was further inoculated to glass vials $(12 \mathrm{ml})$ containing $4 \mathrm{ml}$ NFM medium and followed by incubation at $28 \pm 2{ }^{\circ} \mathrm{C}$ for $24 \mathrm{~h}$. After replacing the steel caps of vials with rubber septa, air $10 \%(\mathrm{v} / \mathrm{v})$ was exchanged with the same volume of acetylene gas with the help of a sterilized syringe followed by incubation at $28 \pm 2{ }^{\circ} \mathrm{C}$ for $24 \mathrm{~h}$. Estimation 
of acetylene $\left(\mathrm{C}_{2} \mathrm{H}_{2}\right)$ reduction to ethylene $\left(\mathrm{C}_{2} \mathrm{H}_{4}\right)$ was made with Gas chromatograph (Thermoquest, Trace GC, Model K, Rodono Milan, Italy) fitted with a Porapak N column $(2 \mathrm{~mm} \times 2 \mathrm{~m})$ and a flame ionization detector (FID). The operating conditions of GC were: oven temperature $80^{\circ} \mathrm{C}$, right inlet $100{ }^{\circ} \mathrm{C}$, right detector $180{ }^{\circ} \mathrm{C}$, hydrogen flow rate $30 \mathrm{ml} \mathrm{min}^{-1}$, nitrogen flow rate $42 \mathrm{ml} \mathrm{min}^{-1}$ and air flow rate was maintained at $300 \mathrm{ml} \mathrm{min}^{-1}$. Standard ethylene $(200 \mu 1$, Spancan Calibration Gas, Spantach Products, England) was injected before analyzing samples and peak area was recorded followed by same volume of each sample. Protein concentration in vial mixture was determined by the method described by Bradford (1976).

\section{Indole-3-acetic acid (IAA) production}

The isolates were inoculated into Erlenmeyer flasks $(500 \mathrm{ml})$ containing $100 \mathrm{ml} \mathrm{LB}$ broth supplemented with tryptophan $\left(100 \mathrm{mg} \mathrm{l}^{-1}\right)$ and subjected to incubation at $28 \pm$ $2{ }^{\circ} \mathrm{C}$ for $48 \mathrm{~h}$ in an orbital shaker at $150 \mathrm{rpm}$ (Gallenhamp, UK). Supernatant, collected in separate tubes after spinning at $13000 \mathrm{~g}$, was acidified ( $\mathrm{pH} 2.8$ ) with $\mathrm{HCl}$. Supernatant was mixed with equal volume of ethyl acetate for IAA extraction in separating funnel (Tien et al., 1979). The IAA-containing upper layer of separating funnel was collected in separate sterilized tubes followed by removal of excessive ethyl acetate under vacuum at $45^{\circ} \mathrm{C}$, using a rotary evaporator (EYELA, Tokyo, Japan). This extract was dissolved in methanol $(1 \mathrm{ml})$ and filter sterilized through $0.2 \mu \mathrm{m}$ nylon filter (Millipore, USA) prior to analyze by HPLC $(\lambda=260 \mathrm{~nm})$ (Perkin Elmer, USA) equipped with Turbochrom software and $C_{18}$ column (150 mm length, $4 \mathrm{~mm}$ diameter and $120 \AA$ pore size) at a flow rate of $0.5 \mathrm{ml} \mathrm{min}^{-1}$ using 30:70 (v/v) methanol:water as mobile phase.

\section{Phosphate solubilization and detection of organic acids}

Each of the purified isolates was spot-inoculated on Pikovskaya's agar (Pikovskaya, 1948) plates, incubated at $28 \pm 2{ }^{\circ} \mathrm{C}$ in a microbial incubator (Memmert, Germany) and observations were taken to $168 \mathrm{~h}$ for halo-zone formation. For quantitative analysis of phosphate solubilization and organic acid production, $100 \mathrm{ml}$ of Pikovskaya's broth was inoculated with single purified colonies of each isolate in Erlenmeyer flasks $(500 \mathrm{ml})$ and incubated at $28 \pm 2{ }^{\circ} \mathrm{C}$ for $240 \mathrm{~h}$ in an orbital shaker (Gallenhamp, UK) at $150 \mathrm{rpm}$. An aliquot of $20 \mathrm{ml}$ of pure bacterial culture from each flask was harvested after after $72 \mathrm{~h}$, $120 \mathrm{~h}$ and $168 \mathrm{~h}$ and centrifuged at $13000 \mathrm{~g}$ for $10 \mathrm{~min}$ to collect the supernatant. The quantification of phosphate solubilization was accomplished according to phosphomolybdate blue color method (Murphy and Riley, 1962) using spectrophotometer (JENWAY6305, UK) $(\lambda=882 \eta \mathrm{m})$. For the determination of the organic acids, the cellfree supernatant of isolates was filtered through nylon filters $(0.2 \mu \mathrm{m}$, Millipore, USA) and $20 \mu \mathrm{l}$ was injected into HPLC $(\lambda=210 \eta \mathrm{m})$ equipped with Turbochrom software (Perkin Elmer, USA) and $\mathrm{C}_{18}$ column (150 mm length, $4 \mathrm{~mm}$ diameter and $120 \AA$ pore size). A flow rate of $0.6 \mathrm{ml} \mathrm{min}{ }^{-1}$ was maintained using methanol: acetic acid (30:70 $(\mathrm{v} / \mathrm{v})$ ) as a mobile phase. The standards of organic acids (gluconic, malic, lactic, acetic, citric, and tartaric acid) were commercially purchased (Sigma-Aldrich, Germany).

\section{ACC deaminase activity}

The ability of endophytes to use 1-aminocyclopropane-1-carboxylic acid (ACC) as sole nitrogen source was determined in $5 \mathrm{ml}$ DF salt minimal media (Penrose and Glick, 
2003) containing $3 \mu \mathrm{l}$ of $0.5 \mathrm{M}$ ACC. The cultures were incubated at $28 \pm 2{ }^{\circ} \mathrm{C}$ at constant shaking $(150 \mathrm{rpm})$ for $48 \mathrm{~h}$. The turbidity of cultures in comparison with noninoculated control indicated the ability to utilize ACC.

\section{Screening for $\mathrm{N}$-acyl homoserine lactone $(\mathrm{AHL})$ production}

The purified isolates (NgE3 and NgE4) were streaked onto the center of a Tryptone Yeast extract (TY) (Beringer, 1974) agar plates and were allowed to grow overnight in a microbial incubator (Memmert, Germany) preset at $28 \pm 2{ }^{\circ} \mathrm{C}$. The indicator strain Chromobacterium violaceum CV026 (obtained from John Innes Centre, Norwich, UK) was grown separately in LB broth at $28 \pm 2{ }^{\circ} \mathrm{C}$ with constant shaking overnight up to an

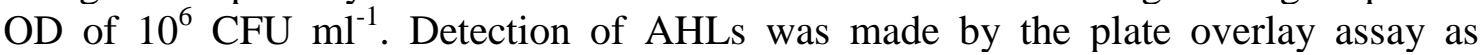
described earlier by McLean et al. (2004). The reference strain A34 (obtained from the John Innes Centre, Norwich, UK) was used as the positive control. A34 is a Rhizobium leguminosarum 8401 containing $p$ RLIJ1. Plates were incubated at $30 \pm 2{ }^{\circ} \mathrm{C}$ overnight, and purple pigmentation produced by the indicator strain on the plates was an indicator of AHL production.

\section{Antifungal activity}

The antifungal activity was tested using a dual-culture assay as described by Sakthivel and Gnanamanickam (1986). A drop of the exponentially grown bacterial culture (approx. $20 \mu \mathrm{l}$ ) was spotted onto potato dextrose agar (PDA) plates close to the walls of the Petri dish on both sides and the plates were allowed to dry in laminar air flow cabinet. A 6-mm agar disk of each of three fungal species, namely, Fusarium solani, F. oxysporum and F. moniliforme, Aspergillus niger and A. flavus (obtained from Department of Plant Pathology, University of Agriculture, Faisalabad, Pakistan), were separately placed at the center of PDA plates. Fungal disc was grown separately over Petri plate containing PDA to serve as a control. The incubation of plates was made at $28 \pm 2{ }^{\circ} \mathrm{C}$ in microbial incubator (Memmert, Germany) for 5 days to measure the inhibition of radial fungal growth between fungal and bacterial colonies.

$$
\text { Inhibition }(\%)=(1-[\text { fungal growth } / \text { Control growth }]) \times 100
$$

\section{$16 S$ rRNA gene sequencing}

Total genomic DNA of isolates ( $\mathrm{NgE} 3$ and $\mathrm{NgE} 4)$ was isolated by the alkaline lysis method (Maniatis et al., 1982) and quantified by ultraspec ${ }^{\mathrm{TM}} 3100\left(\mathrm{OD}_{260}, 260 / 280\right)$. This DNA was used as template to amplify the $16 \mathrm{~S}$ rRNA gene with primers fD1 and rD1 as described earlier by Weisburg et al. (1991) with slight modifications as: for $50 \mu \mathrm{L}$ reaction in ultra-pure water, $5 \mu \mathrm{l}$ of Taq buffer (Fermentas, USA), $3 \mu \mathrm{l}$ of $25 \mathrm{mM} \mathrm{MgCl}_{2}$ (Fermentas, USA), $5 \mu \mathrm{l}$ of $2 \mathrm{mM}$ dNTPs (Fermentas, USA), $0.5 \mu \mathrm{l}$ of $100 \%$ DMSO, 1.5 $\mu \mathrm{l}$ each of forward and reverse primer, $0.75 \mu \mathrm{l}$ of $5 \mathrm{U}^{-1}$ Taq DNA polymerase (Fermentas, USA) and $40 \eta \mathrm{g}$ of template DNA. Polymerase chain reaction (PCR) was conducted in thermal cycler (PeQLab, advanced Primus 96, Germany) with modified temperature conditions as: 30 cycles of $95{ }^{\circ} \mathrm{C}$ for $1 \mathrm{~min}, 55^{\circ} \mathrm{C}$ for $30 \mathrm{~s}$, and $72{ }^{\circ} \mathrm{C}$ for $1 \mathrm{~min}$. The initial denaturation and final extension steps were performed at $95{ }^{\circ} \mathrm{C}$ for $5 \mathrm{~min}$ and $72^{\circ} \mathrm{C}$ for $10 \mathrm{~min}$, respectively. Amplicons were purified with QIAquick PCR purification kit (Qiagen, USA) according to manufacturer's protocol and sequenced 
directly on both sides (Macrogen, Korea). The gene sequence was analyzed using sequence scanner software package. Forward and reverse sequenced strands were joined by Caps 3 assembly online software and compared with others in the GenBank database using the NCBI BLASTn tool. Final sequences were deposited in Genbank and accession numbers were obtained.

\section{Ultrastructure studies}

For ultrastructure-studies, tomato (cv. Nagina) seeds were surface sterilized by immersing them in an aqueous solution of sodium hypochlorite $(5 \%(\mathrm{v} / \mathrm{v}))$ for $10 \mathrm{~min}$ followed by 5-6 washings with sterilized distilled water. The seeds were soaked in the inoculum $\left(1 \times 10^{8} \mathrm{CFU} \mathrm{ml}{ }^{-1}\right)$ for $30 \mathrm{~min}$ and allowed to germinate on water-agar $(1.5 \%$ $(\mathrm{w} / \mathrm{v}))$ plates. Root hairs of ten days old seedlings were cut into pieces (approximately $1-3 \mathrm{~cm})$ and embedded in water-agar $(1.5 \%(\mathrm{w} / \mathrm{v}))$ again followed by cutting of approximately $2-3 \mathrm{~mm}$ small agar cubes. The cubes were put in $1.5-\mathrm{ml}$ tubes in the presence of $5 \%(\mathrm{v} / \mathrm{v})$ gluteraldehyde (made in 0.2 M PIPES buffer, $\mathrm{pH} 8.0$ ) as a fixative. After 16-18 h, the fixative was replaced with $0.2 \mathrm{M}$ PIPES buffer [0.58 $\mathrm{g} \mathrm{NaCl}$, $3 \mathrm{~g}$ PIPES \{piperazine- $N, N^{\prime}$ bis(2-ethanesulfonic acid)\}, $1 \mathrm{M} \mathrm{NaOH}, 0.2 \mathrm{~g} \mathrm{MgCl}_{2} \cdot 6 \mathrm{H}_{2} \mathrm{O}$, $\mathrm{pH}$ 6.8] (Salema and Brandao, 1973) and samples were washed $2 \times 1 \mathrm{~h}$ in fresh buffer. Afterwards, these samples were treated with aqueous osmium tetra oxide $(0.2 \%(\mathrm{w} / \mathrm{v})$ made in PIPES buffer solution $(0.2 \mathrm{M}, \mathrm{pH}$ 6.8) for 16-18 $\mathrm{h}$ and washed $2 \times 30 \mathrm{~min}$ with sterilized distilled water. After treating with aqueous uranyl acetate $(5 \%$ (w/v) for 16$18 \mathrm{~h}$, the samples were washed with sterilized distilled water for $2 \times 30 \mathrm{~min}$. First dehydration was carried out with absolute alcohol for $2 \times 30 \mathrm{~min}$ and then with propylene oxide $(100 \%(\mathrm{v} / \mathrm{v}))$ for $1 \times 30 \mathrm{~min}$. Infiltration of samples was carried out with propylene oxide in ratio 1:1 for 24-48 $\mathrm{h}$ and then with spur-resin for further 24-72 h. The accelerator Benzyl Di-Methyl Amine (BDMA) was used in all infiltration steps. Samples were placed on flat embedding molds for polymerization for $72 \mathrm{~h}$ at $65-70{ }^{\circ} \mathrm{C}$ in the oven (Memmert, Germany). Polymerized resin blocks were left at room temperature for at least $24 \mathrm{~h}$ before cutting ultra-thin sections. Ultra-thin sections (150$200 \mathrm{~nm}$ ) were cut on ultra-microtome (RMC-7000) and the sections were carefully placed on copper grids. The sections were double stained with uranyl acetate and lead citrate for $30 \mathrm{~min}$ and $10 \mathrm{~min}$, respectively. The grids were washed with deionized water and observed under Transmission Electron Microscope (TEM, JEOL 1010, Japan).

\section{Results}

\section{Morphological and physiological characterization}

Isolate $\mathrm{NgE} 3$ was appeared with round and whitish colonies on agar medium and its cells were found as long rods under a light microscope. In addition, it showed $73.93 \pm$ $4.23 \eta \mathrm{mol} \mathrm{mg}^{-1}$ protein $\mathrm{h}^{-1}$ nitrogenase activity and $4.92 \pm 0.64 \mu \mathrm{g} \mathrm{ml}^{-1}$ IAA production ability (Table 1). Isolate $\mathrm{NgE3}$ was also found positive for AHLs production and demonstrated substantial (> 79\%) inhibition of three fungal pathogens viz. Fusarium oxysporum, Aspergillus niger and A. flavus. On the other hand, isolate $\mathrm{NgE} 4$ had curled and off-white colonies with cell shapes appeared as short rods under a light microscope. Nitrogenase activity of $\mathrm{NgE} 4$ was measured as $63.00 \pm 6.35 \eta \mathrm{mol} \mathrm{mg}{ }^{-1}$ protein ${ }^{-1}$. It also synthesized $1.66 \pm 0.11 \mu \mathrm{g} \mathrm{ml}^{-1}$ IAA in the culture medium (Table 2). In addition, 
isolate $\mathrm{NgE4}$ also showed biocontrol potential (> 79\%) against Fusarium solani, $F$. oxysporum and Aspergillus flavus (Table 3), but was found negative found for AHLs production. was ACC deaminase and catalase enzyme activity was found positive in both isolates. Moreover, both the isolates were found Gram-positive showing the cell motility glass slide. Isolates $\mathrm{NgE} 3$ and $\mathrm{NgE} 4$ were unable to show the antifungal activity against a panel of fungal pathogens tested and also lacked AHL production.

Table 1. Morphological and physiological characterization of isolates $\mathrm{NgE3}$ and $\mathrm{NgE4}$

\begin{tabular}{|c|c|c|c|c|}
\hline Isolate $^{* *}$ & $\begin{array}{c}\text { Colony } \\
\text { morphology }\end{array}$ & Cell morphology & $\begin{array}{l}\text { IAA production } \\
\left(\mu \mathrm{g} \mathrm{ml}^{-1}\right)\end{array}$ & AHLs production \\
\hline $\mathrm{NgE} 3$ & $\begin{array}{l}\text { Round and } \\
\text { whitish }\end{array}$ & Long rods & $4.92(0.64)$ & + \\
\hline $\mathrm{NgE} 4$ & $\begin{array}{l}\text { Curled and off- } \\
\text { white }\end{array}$ & Short rods & $1.66(0.11)$ & - \\
\hline
\end{tabular}

**Both isolates were Gram-positive and motile. Isolates $\mathrm{NgE} 3$ and $\mathrm{NgE} 4$ were also found positive for catalase and ACC deaminase activity. Standard error of three replicates is presented in parentheses

Table 2. The antifungal activity of bacterial endophytes from the tomato against different fungal pathogens

\begin{tabular}{|c|c|c|c|c|c|}
\hline \multirow{3}{*}{ Isolate } & \multicolumn{5}{|c|}{$\%$ inhibition } \\
\hline & \multicolumn{3}{|c|}{ Fusarium } & \multicolumn{2}{|c|}{ Aspergillus } \\
\hline & solani & oxysporum & moniliforme & niger & flavus \\
\hline $\mathrm{NgE3}$ & $46(5)^{*}$ & $78(4)$ & $51(11)$ & $76(5)$ & $79(3)$ \\
\hline $\mathrm{NgE} 4$ & $77(6)$ & $83(6)$ & $42(3)$ & $66(10)$ & $86(13)$ \\
\hline
\end{tabular}

*Standard error of three replicates is presented in parentheses

Table 3. Phylogenetic identity of `16S rRNA gene sequences after BLASTn analysis

\begin{tabular}{c|c|c|c|c|l}
\hline Isolate & $\begin{array}{c}\text { Sequence } \\
\text { length (bp) }\end{array}$ & $\begin{array}{c}\text { Similarity } \\
\mathbf{\%}\end{array}$ & Closest GenBank match & Strain identified & Accession \# \\
\hline NgE3 & 1057 & 99 & $\begin{array}{c}\text { Bacillus subtilis subsp. } \\
\text { subtilis strain DDKRC2 }\end{array}$ & Bacillus subtilis & KC202298 \\
NgE4 & 857 & 98 & Paenibacillus sp. IHB B 3310 & Paenibacillus sp. & KC202299 \\
\hline
\end{tabular}

\section{Relationship between phosphate solubilization and organic acid production}

Isolate $\mathrm{NgE} 3$ solubilized $44.71 \pm 2.25 \mu \mathrm{g} \mathrm{ml}^{-1}$ insoluble tricalcium phosphate (TCP) after $168 \mathrm{~h}$ of incubation with the drop in the $\mathrm{pH}$ of the medium up to 5.3, which was found directly correlated $(P \leq 0.001, r=0.97)$ to synthesis of lactic acid in the culture medium $\left(21.89 \pm 1.66 \mu \mathrm{g} \mathrm{ml}^{-1}\right)$. Similarly, isolate $\mathrm{NgE} 4$ converted $54.40 \pm 1.92 \mu \mathrm{g} \mathrm{ml}^{-1}$ of TCP to soluble form with the total lowering of $\mathrm{pH}$ up to 4.2. The amount of TCP solubilized by $\mathrm{NgE} 4$ was positively correlated to both gluconic acid $(P \leq 0.001$, $r=0.99)$ and lactic acid $(P \leq 0.001, r=0.99)$. The total amount of gluconic and lactic 
acids produced by NgE4 after $168 \mathrm{~h}$ of incubation were measured as $19.40 \pm 0.82 \mu \mathrm{g}$ $\mathrm{ml}^{-1}$ and $14.06 \pm 0.85 \mu \mathrm{g} \mathrm{ml}^{-1}$, respectively (Fig. 1).
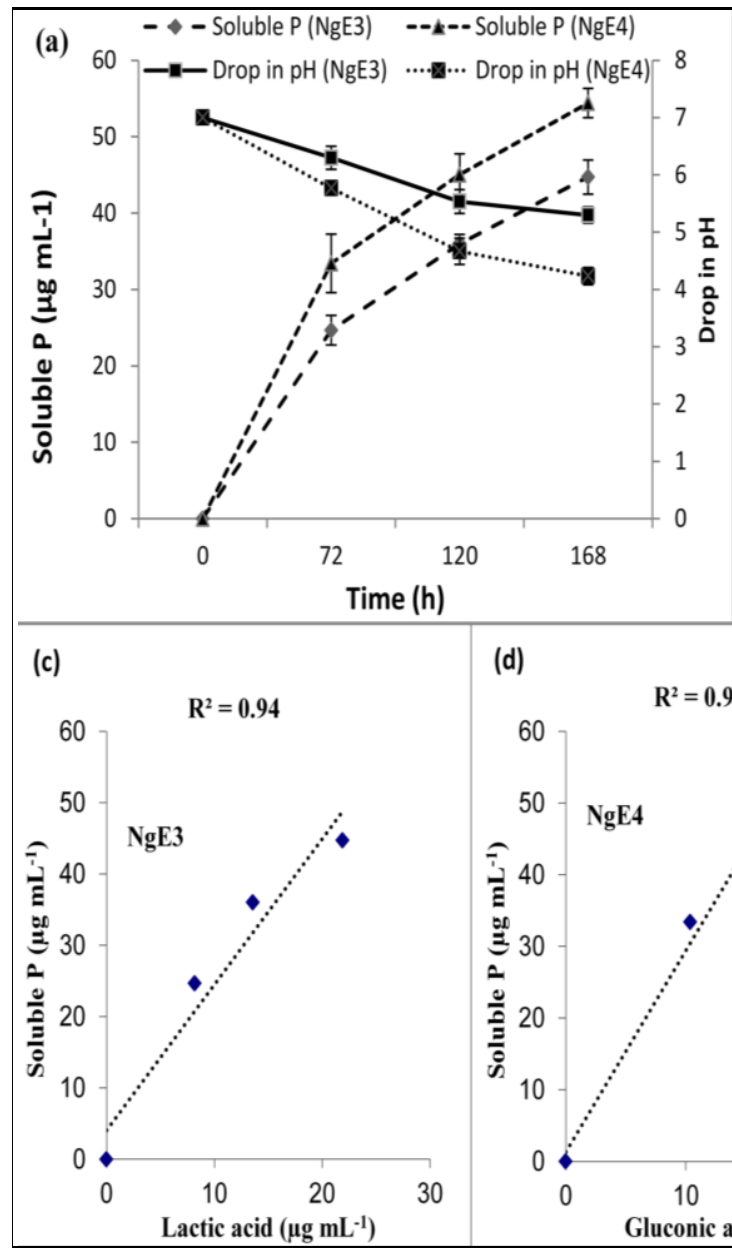

(d)
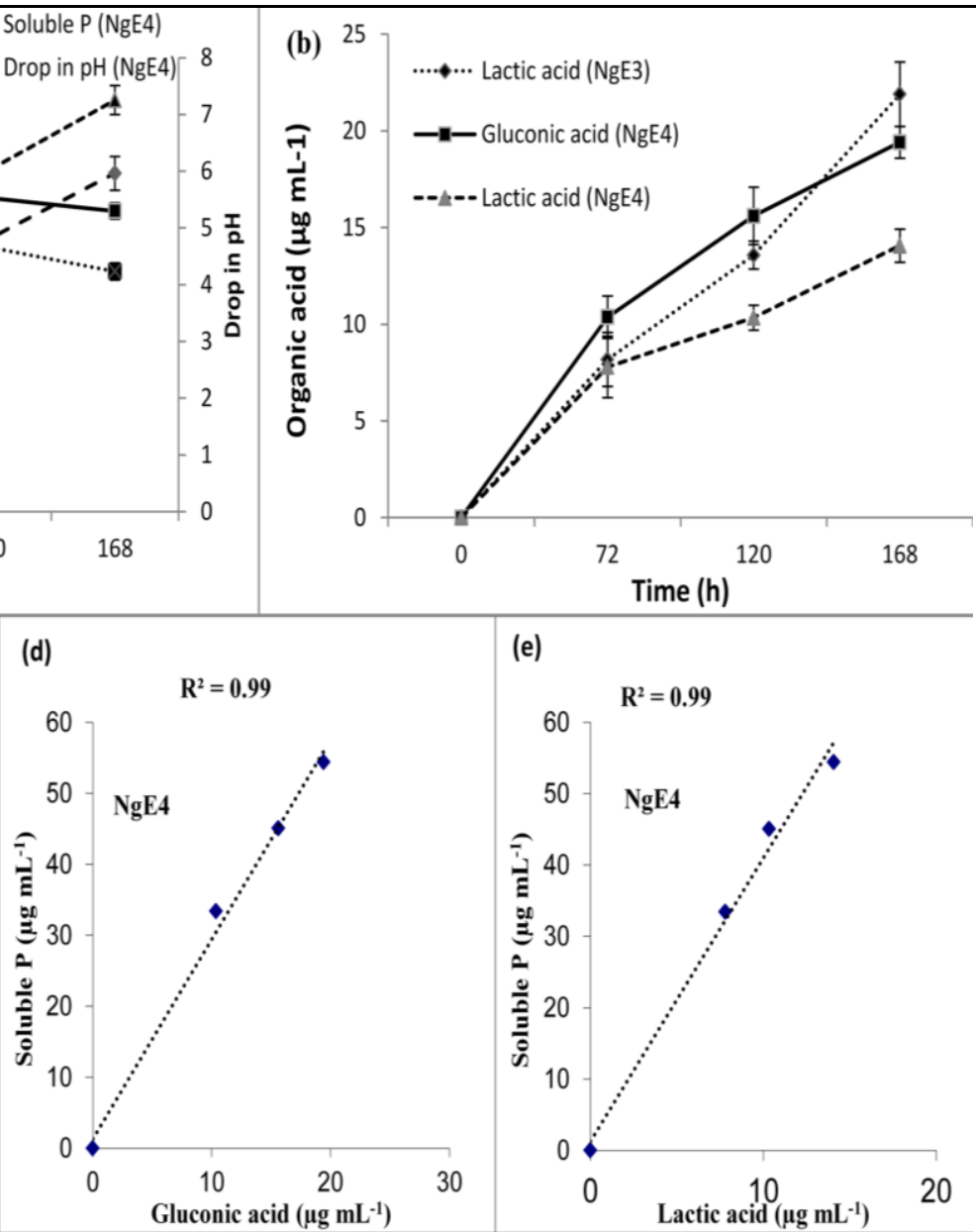

(e)

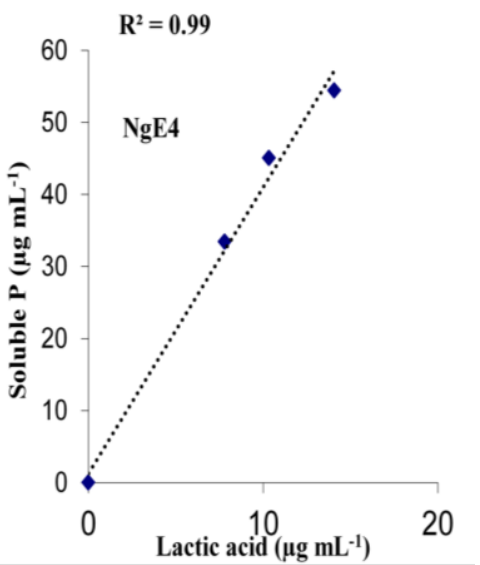

Figure 1. Phosphate solubilized by isolates $\mathrm{NgE3}$ and $\mathrm{NgE4}$ with respect to drop in $\mathrm{pH}$ of medium (a), organic acids produced by the isolates at time intervals $(b)$ and relationship between organic acid production and phosphate solubilization as determined through regression correlation analysis $(c, d, e)$

\section{Molecular identification and phylogenetic analysis}

Isolate NgE3 was identified as Bacillus subtilis (KC202298) on the basis of 16S rRNA gene sequence analysis (Table 3). In phylogenetic tree, constructed to compare strain NgE3 with type strains of genus Bacillus, it clustered itself with Bacillus subtilis NCDO $1769^{\mathrm{T}}$ and Bacillus subtilis IAM $12118^{\mathrm{T}}$. On the other hand, NgE4 was identified as Paenibacillus sp. as it demonstrated 98\% 16S rRNA gene sequence similarity with more than one Paenibacillus spp. Phylogenetic tree showed its grouping with P. pabuli JCM $9074^{\mathrm{T}}$ and P. illinoisensis $\mathrm{JCM} 9907^{\mathrm{T}}$ (Fig. 2).

\section{Ultrastructure studies for root colonization}

When observed by TEM, both Bacillus subtilis NgE3 and Paenibacillus sp. NgE4 infected the tomato root hair cells under gnotobiotic conditions. The colonization 
pattern of both strains apparently looked similar with the only difference in the number of bacterial cells infected the tomato root hair cells was greater in case of Paenibacillus sp. NgE4. Both the strains were found potential bacterial endophytes through ultrastructure TEM studies (Fig. 3).

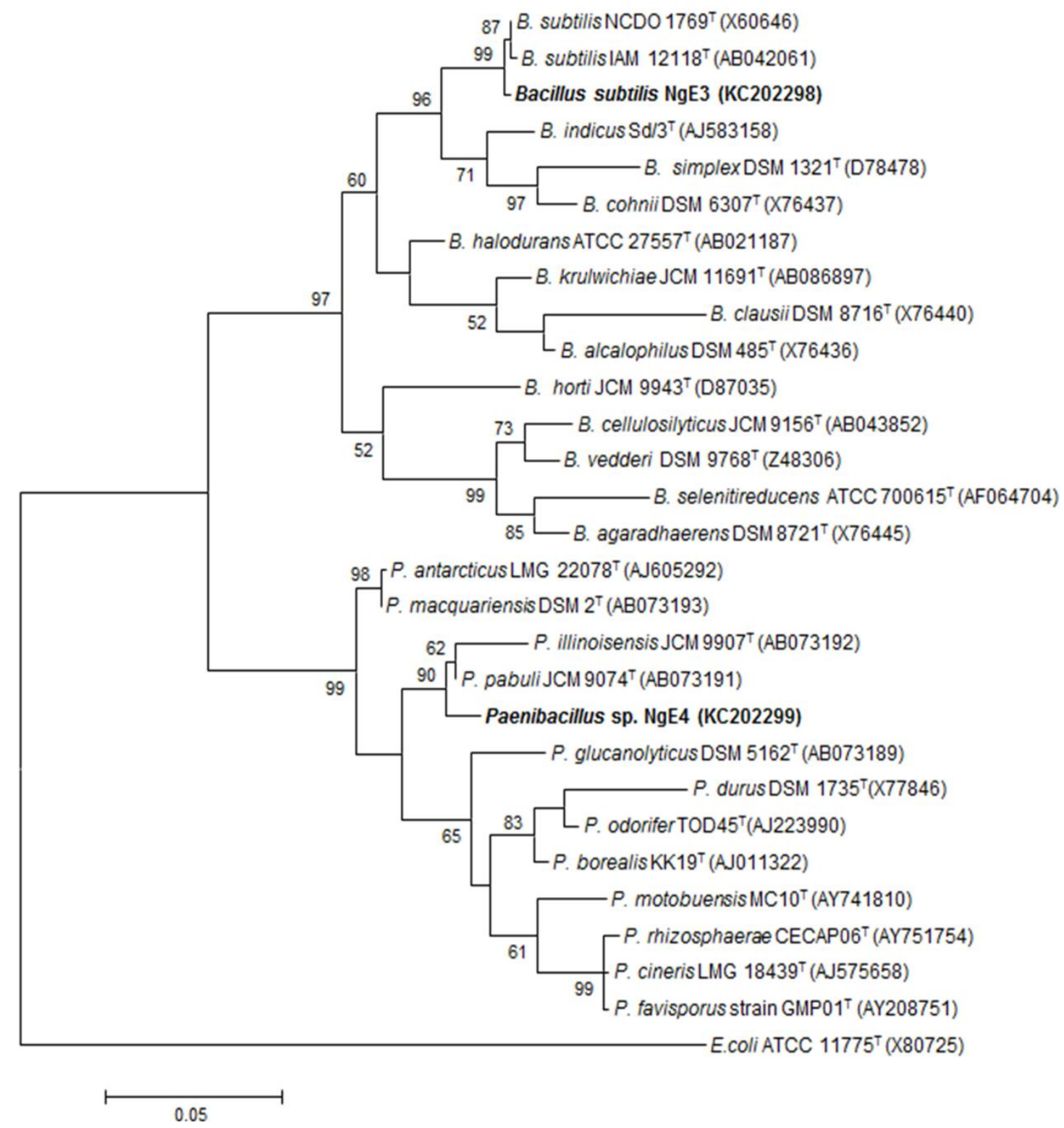

Figure 2. Phylogenetic analysis based on $16 \mathrm{~S} r R N A$ gene sequences of strains $N g E 3$ and NgE4 with their respective type strains. The evolutionary history was inferred using the Neighbor-

Joining method. Only greater than 50\% of replicate trees in which the associated taxa clustered together in the bootstrap test (1000 replicates) are shown next to the branches. The tree is drawn to scale, with branch lengths in the same units as those of the evolutionary distances used to infer the phylogenetic tree. The evolutionary distances were computed using the Maximum Composite Likelihood method and are in the units of the number of base substitutions per site. Evolutionary analyses were conducted in Phylmyl software package. E. coli strain ATCC $11775^{T}$ was included as an outgroup 


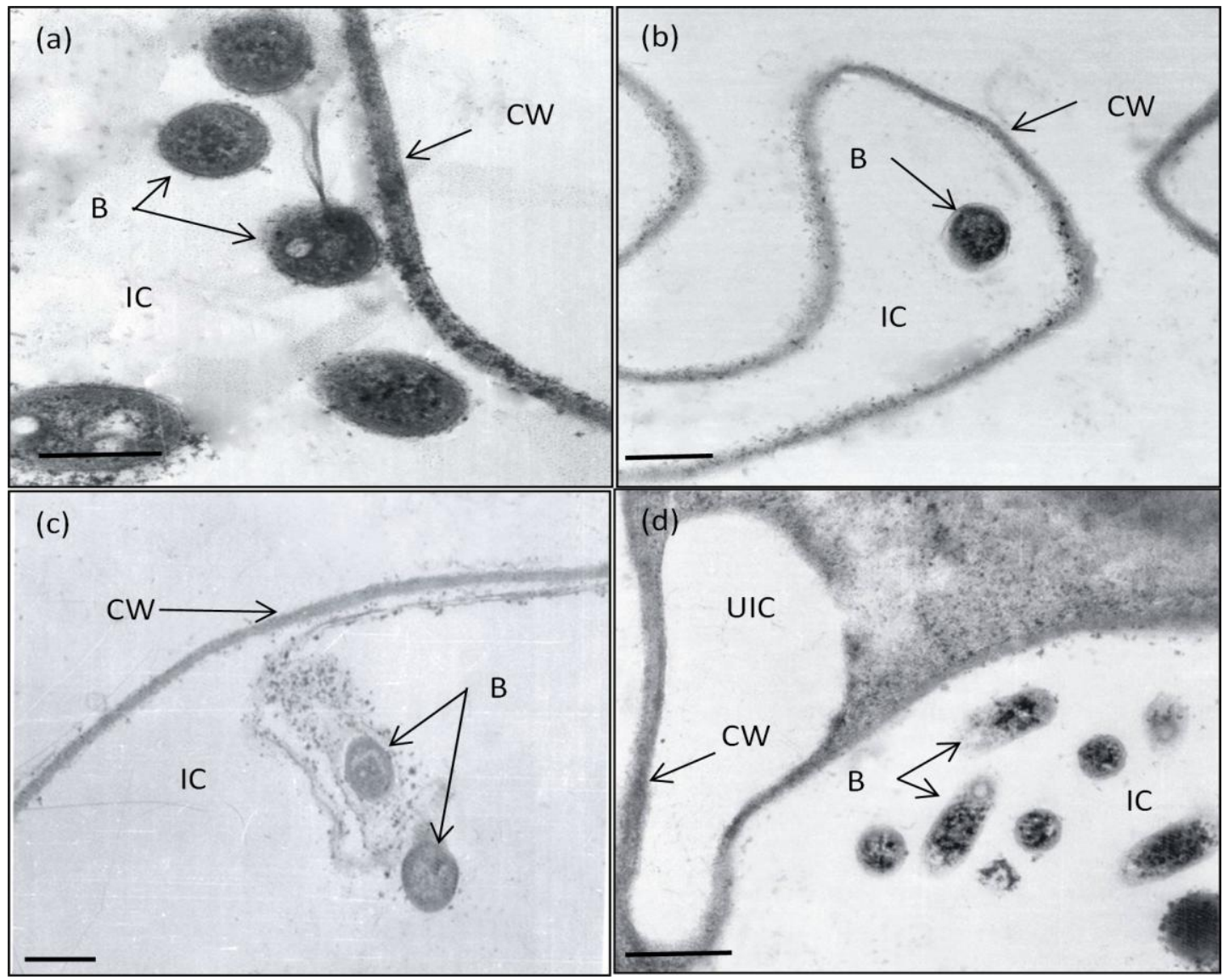

Figure 3. Tomato root endosphere colonization of strains Bacillus subtilis $\mathrm{NgE3}(a, b)$ and Paenibacillus sp. NgE4 (c, d). B Bacteria, CW Cell wall, IC Infected cell, UIC Uninfected cell. Scale bar: $1 \mu \mathrm{m}$

\section{Discussion}

Recently, endophytic bacteria have gained significant attention due to their interesting features related to plant growth and health issues. A very limited research is available on exploiting the potential of bacterial endophytes in Pakistan. The present study demonstrated the in vitro efficiency of Bacillus subtilis $\mathrm{NgE} 3$ and Paenibacillus sp. NgE4 in terms of nitrogen fixation, P-solubilization through organic acid production, synthesis of IAA, ACC deaminase activity, AHLs production and biocontrol potential. Globally, bacterial endophytes have already been reported to exhibit phytobeneficial characteristics (Gyaneshwar et al., 2001; Miliūtè and Buzaite, 2011; Oteino et al., 2015) and stress tolerance (Khan et al., 2015).

Reduction of acetylene $\left(\mathrm{C}_{2} \mathrm{H}_{2}\right)$ into ethylene $\left(\mathrm{C}_{2} \mathrm{H}_{4}\right)$ is an indirect approach to authenticate the diastrophic nature of bacteria. Conversion of a significant amount of acetylene by $\mathrm{NgE3}$ and $\mathrm{NgE} 4\left(73.93 \pm 4.23 \mu \mathrm{g} \mathrm{m}{ }^{-1}\right.$ and $63.00 \pm 6.35 \mu \mathrm{g} \mathrm{ml}{ }^{-1}$, respectively) into ethylene confirmed the nitrogen-fixing ability of the strains. Gyaneshwar et al. (2001) reported bacterial endophyte Serratia marcescens IRBG500 as diazotroph on the basis its acetylene reduction ability and nifH gene sequence analysis. Bacteria make inorganic soil phosphates available to plants through the secretion or organic acids in plant vicinity (Richardson et al., 2009; Shahid et al., 2015). Secretion of low molecular weight organic acids in soil by phosphate solubilizing bacteria is the major 
mechanism that works through acidification of soil or media (Gyaneshwar et al., 1999; Puente et al., 2004; Khan et al., 2009). Through their hydroxyl and carboxyl groups, these organic acids play their role in detaching the cations bound to soil phosphates (Alphosphates, Ca-phosphates and Fe-phosphates) transforming them into primary and secondary ortho-phosphates (Kpomblekou and Tabatabai, 1994). Moreover, extracellular oxidation of glucose to GA via quinoprotein glucose dehydrogenase is the most effective mineral phosphate solubilization phenotype in Gram-negative bacteria (Rodríguez et al., 2000). In our study, phosphate solubilization by strains $\mathrm{NgE3}$ and $\mathrm{NgE} 4$ was found significantly correlated with gluconic acid $(P \leq 0.001, r=0.99)$ and lactic acid $(P \leq 0.001$, $r=0.99)$ (Fig 1). The amount of IAA produced by stains NgE3 and NgE4 $(4.92 \pm 0.64 \mu \mathrm{g}$ $\mathrm{ml}^{-1}$ and $1.66 \pm 0.11 \mu \mathrm{g} \mathrm{ml}^{-1}$ ) is also similar to the findings of Miliūte and Buzaite (2011) who isolated 9 bacterial endophytes from apple tree buds and all of them were able to produce IAA in vitro. The positive reaction of both strains for ACC deaminase enzyme activity aided their significance for plant growth under stress conditions (Penrose and Glick, 2003; Glick et al., 2007; Mahmood et al., 2017). Similarly, biocontrol potential of isolates $\mathrm{NgE} 3$ and $\mathrm{NgE} 4$ against major phytopathogenic fungal strains is in agreement with the previous findings (Senthilkumar et al., 2009; Wang et al., 2013), which revealed antifugal activity of screened bacterial endophytes against many fungal pathogens including Fusarium and Aspergillus spp. $N$-acylhomoserine lactone (AHL)-based quorum sensing (QS) systems have been described in many bacterial endophytes (Liu et al., 2011), but in current study one of the two isolates NgE3 demonstrated AHLs production trait. Besides other plants, bacterial endophytes have also been isolated and characterized for plant growth-promoting attributes (Amaresan et al., 2012), biocontrol activity (Munif et al., 2013; Upreti and Thomas, 2015) and production of AHLs (Singh et al., 2015) from tomato plant.

The in vitro demonstration of plant-beneficial attributes and biocontrol efficiency led to the identification of $\mathrm{NgE} 3$ and $\mathrm{NgE} 4$ on molecular basis through the sequencing of the most accepted taxonomic marker, the $16 \mathrm{~S}$ rRNA gene. Isolate $\mathrm{NgE} 3$ was identified as Bacillus subtilis and isolate NgE4 as Paenibacillus sp. with $99 \%$ and $98 \%$ sequence identity, respectively (Table 3). In the neighbor-joining phylogenetic tree, Bacillus subtilis NgE3 clustered itself with Bacillus subtilis NCDO $1769^{\mathrm{T}}$ and Bacillus subtilis IAM $12118^{\mathrm{T}}$. On the other hand, Paenibacillus sp. NgE4 grouped itself with P. pabuli JCM $9074^{\mathrm{T}}$ and P. illinoisensis $\mathrm{JCM} 9907^{\mathrm{T}}$ (Fig. 2). Earlier, endophytes from genus Bacillus and Paenibacillus have been reported to carry plant beneficial characteristics. Malfanova et al. (2011) isolated Bacillus subtilis HC8 from the giant hogweed Heracleum sosnowskyi Manden, which significantly promoted plant growth and protected tomato against tomato foot and root rot. Many Paenibacillus spp. with positive effects on plant growth have been isolated by Ulrich et al. (2008) from poplar, larch and spruce. Similarly, it was concluded that inoculation of Paenibacillus sp. strongly affected the metabolic composition of in vitro-grown plants (Scherling et al., 2009).

Root colonization efficiency of Bacillus subtilis $\mathrm{NgE3}$ and Paenibacillus sp. NgE4 was confirmed through ultra-structure studies (Fig. 3). Both strains infected tomato root hair cells. Paenibacillus sp. NgE4 densely colonized the endosphere of tomato root hair cells compared to Bacillus subtilis NgE3. Both the strains were found potential bacterial endophytes through ultrastructure TEM studies. Plant beneficial bacteria, as epiphytes and endophytes have been routinely localized in rhizosphere and endosphere with TEM and immunogold labeling techniques (Schloter et al., 1997; Hameed et al., 2005; Jeun et al., 2008; Yasmeen et al., 2012; Shahid et al., 2015). 


\section{Conclusion}

The bacterial endophytes $\mathrm{NgE} 3$ and $\mathrm{NgE} 4$ had great in vitro potential for major plant beneficial traits. Prior to their addition to indigenous biofertilizer regimes, the strains might be inoculated directly to tomato plants under pot and field experiments to check their effect on plant growth and disease suppression.

Acknowledgements. Authors are thankful to Higher Education Commission (HEC), Pakistan for proving funds for this research under HEC $5000 \mathrm{PhD}$ Fellowship program. We would like to express our gratitude to Mr. Javed Iqbal, Electron Microscopist, NIBGE, Faisalabad, Pakistan for his technical help in ultrastructure studies. Technical help of Microbial Physiology Laboratory staff at NIBGE is thankfully acknowledged.

\section{REFERENCES}

[1] Akram, M. S., Shahid, M., Tariq, M., Azeem, M., Javed, M. T., Saleem, S., Riaz, S. (2016): Deciphering Staphylococcus sciuri mediated anti-oxidative defence mechanisms and growth modulations in salt stressed maize. - Frontiers in Microbiology 7: 867.

[2] Amaresan, N., Jayakumar, V., Kumar, K., Thajuddin, N. (2012): Isolation and characterization of plant growth promoting endophytic bacteria and their effect on tomato (Lycopersicon esculentum) and chilli (Capsicum annuum) seedling growth. - Annals of Microbiology 62: 805-810.

[3] Amjad, M., Akhtar, J., Anwar-ul-Haq, M., Ahmad, R., Zaid, M. (2014a): Characterization of comparative response of fifteen tomato (Lycopersicon esculentum Mill.) genotypes to $\mathrm{NaCl}$ stress. - Journal of Agricultural Science and Technology 16: 851-862.

[4] Amjad, M., Akhtar, J., Anwar-Ul-Haq, M., Imran, S., Jacobsen, S. E. (2014b): Soil and foliar application of potassium enhances fruit yield and quality of tomato under salinity. Turkish Journal of Biology 38: 208-218.

[5] Beringer, J. (1974): R factor transfer in Rhizobium leguminosarum. - Journal of General Microbiology 84: 188-198.

[6] Bradford, M. M. (1976): A rapid and sensitive method for the quantitation of microgram quantities of protein utilizing the principle of protein-dye binding. - Annals of Biochemistry 72: 248-254.

[7] Bulgarelli, D., Schlaeppi, K., Spaepen, S., van Themaat, E. V. L., Schulze-Lefert, P. (2013): Structure and functions of the bacterial microbiota of plants. - Annual Reviews of Plant Biology 64: 807-838.

[8] Damodaran, T., Rai, R., Jha, S., Kannan, R., Pandey, B., Sah, V., Mishra, V., Sharma, D. (2014): Rhizosphere and endophytic bacteria for induction of salt tolerance in gladiolus grown in sodic soils. - Journal of Plant Interactions 9: 577-584.

[9] Gaiero, J. R., McCall, C. A., Thompson, K. A., Day, N. J., Best, A. S., Dunfield, K. E. (2013): Inside the root microbiome: bacterial root endophytes and plant growth promotion. - Americal Journal of Botany 100: 1738-1750.

[10] Glick, B. R., Todorovic, B., Czarny, J., Cheng, Z., Duan, J., McConkey, B. (2007): Promotion of plant growth by bacterial ACC deaminase. - Critical Reviews Plant Sciences 26: 227-242.

[11] Gyaneshwar, P., Parekh, L., Archana, G., Poole, P., Collins, M., Hutson, R., Kumar, G. N. (1999): Involvement of a phosphate starvation inducible glucose dehydrogenase in soil phosphate solubilization by Enterobacter asburiae. - FEMS Microbiology Letters 171: 223-229. 
[12] Gyaneshwar, P., James, E. K., Mathan, N., Reddy, P. M., Reinhold-Hurek, B., Ladha, J. K. (2001): Endophytic colonization of rice by a diazotrophic strain of Serratia marcescens. - Journal of Bacteriology 183: 2634-2645.

[13] Hameed, S., Mubeen, F., Malik, K. A., Hafeez, F. Y. (2005): Nodule Co-occupancy of Agrobacterium and Bradyrhizobium with Potential Benefit to Legume Host. In: Wang, Y. P. (eds). Biological Nitrogen Fixation, Sustainable Agriculture and the Environment. Springer, Dordrecht.

[14] Hanif, K., Hameed, S., Imran, A., Naqqash, T., Shahid, M., Van-Elsas, J. D. (2015): Isolation and characterization of a $\beta$-propeller gene containing phosphobacterium Bacillus subtilis strain KPS-11 for growth promotion of potato (Solanum tuberosum L.). Frontiers in Microbiology 6: 1-12.

[15] Hardoim, P. R., van Overbeek, L. S., van Elsas, J. D. (2008): Properties of bacterial endophytes and their proposed role in plant growth. - Trends in Microbiology 16: 463471.

[16] Hardy, R. W., Holsten, F. R. D., Jackson, E. K., Burns, R. E. (1968): The acetyleneethylene assay for nitrogen fixation: Laboratory and field evaluation. - Plant Physiology 43: 1185-1207.

[17] Hartmann A., Rothballer, M., Hense, B. A., Schroder, P. (2014): Bacterial quorum sensing compounds are important modulators of microbe-plant interactions. - Frontiers in Plant Science 5: 131.

[18] Hurek, T., Reinhold-Hurek, B., Van Montagu, M., Kellenberger, E. (1994): Root colonization and systemic spreading of Azoarcus sp. strain BH72 in grasses. - Journal of Bacteriology 176: 1913-1923.

[19] Jasim, B., Joseph, A. A., John, C. J., Mathew, J., Radhakrishnan, E. (2014): Isolation and characterization of plant growth promoting endophytic bacteria from the rhizome of Zingiber officinale. - 3 Biotechnology 4: 197-204.

[20] Jeun, Y. C., Lee, Y. J., Kim, K. W., Kim, S. J., Lee, S. W. (2008): Ultrastructures of Colletotrichum orbiculare in the leaves of cucumber plants expressing induced systemic resistance mediated by glomus intraradices BEG110. - Mycobiology 36: 236-241.

[21] Khan, A. A., Jilani, G., Akhtar, M. S., Naqvi, S. M. S., Rasheed, M. (2009): Phosphorus solubilizing bacteria: occurrence, mechanisms and their role in crop production. - Journal of Agricultural Biological Science 1: 48-58.

[22] Khan, M. U., Sessitsch, A., Harris, M., Fatima, K., Imran, A., Arslan, M., Shabir, G., Khan, Q. M., Afzal, M. (2015): Cr-resistant rhizo-and endophytic bacteria associated with Prosopis juliflora and their potential as phytoremediation enhancing agents in metaldegraded soils. - Fronties in Plant Sciences 5: 755.

[23] Kloepper, J. W., Lifshitz, R., Zablotowicz, R. M. (1989): Free-living bacterial inocula for enhancing crop productivity. - Trends in Biotechnology 7: 39-44.

[24] Kpomblekou, K., Tabatabai, M. (1994): Effect of organic acids on release of phosphorus from phosphate rocks. - Soil Science 158: 442-453.

[25] Liu, X., Jia, J., Popat, R., Ortori, C. A., Li, J., Diggle, S. P., Gao, K., Cámara, M. (2011): Characterisation of two quorum sensing systems in the endophytic Serratia plymuthica strain G3: differential control of motility and biofilm formation according to life-style. BMC Microbiology 11: 26-34.

[26] Mahmood, F., Shahid, M., Hussain, S., Shahzad, T., Tahir, M., Ijaz, M., Hussain, A., Mahmood, K., Imran, M., Babar, S. A. K. (2017): Potential plant growth promoting strain Bacillus sp. SR-2-1/1 decolorized azo dyes through NADH-ubiquinone oxidoreductase activity. - Bioresource Technology 235: 176-184.

[27] Malfanova, N., Kamilova, F., Validov, S., Shcherbakov, A., Chebotar, V., Tikhonovich, I., Lugtenberg, B. (2011): Characterization of Bacillus subtilis HC8, a novel plant-beneficial endophytic strain from giant hogweed. - Microbial Biotechnology 4: 523-532. 
[28] Maniatis, T., Fritsch, E. F., Sambrook, J. (1982): Molecular Cloning; A Laboratory Manual, $2^{\text {nd }}$ ed. - Cold Spring Harbor Laboratory, Cold Spring Harbor, NY.

[29] McLean, R. J., Pierson, L. S., Fuqua, C. (2004): A simple screening protocol for the identification of quorum signal antagonists. - Journal of Microbiological Methods 58: 351-360.

[30] Miliūtè, I., Buzaitè, O. (2011): IAA production and other plant growth promoting traits of endophytic bacteria from apple tree. - Biologija 57: 98-102.

[31] Munif, A., Hallmann, J., Sikora, R. A. (2013): Isolation of root endophytic bacteria from tomato and its biocontrol activity against fungal diseases. - Microbiology Indonesia 6: 148-156.

[32] Murphy, J., Riley, J. P. (1962): Modified solution method for determination of phosphate in natural water. - Analytica Chimica Acta 27: 31-36.

[33] Okon, Y., Albrecht, S. L., Burris, R. H. (1977): Methods for growing Spirillum lipoferum and for counting it in pure culture and in association with plants. - Applied and Environmental Microbiology 33: 85-88.

[34] Oteino, N., Lally, R. D., Kiwanuka, S., Lloyd, A., Ryan, D., Germaine, K. J., Dowling, D. N. (2015): Plant growth promotion induced by phosphate solubilizing endophytic Pseudomonas isolates. - Frontiers in Microbiology 6: 1-9.

[35] Penrose, D. M., Glick, B. R. (2003): Methods for isolating and characterizing ACC deaminase-containing plant growth-promoting rhizobacteria. - Physiology Plantarum 118: 10-15.

[36] Pii, Y., Mimmo, T., Tomasi, N., Terzano, R., Cesco, S., Crecchio, C. (2015): Microbial interactions in the rhizosphere: beneficial influences of plant growth-promoting rhizobacteria on nutrient acquisition process: A review. - Biology and Fertility of Soils 51: 403-415.

[37] Puente, M., Bashan, Y., Li, C., Lebsky, V. (2004): Microbial populations and activities in the rhizoplane of rock-weathering desert plants. I. Root colonization and weathering of igneous rocks. - Plant Biology 6: 629-642.

[38] Richardson, A. E., Barea, J. M., McNeill, A. M., Prigent-Combaret, C. (2009): Acquisition of phosphorus and nitrogen in the rhizosphere and plant growth promotion by microorganisms. - Plant and Soil 321: 305-339.

[39] Rodríguez, H., Gonzalez, T., Selman, G. (2000): Expression of a mineral phosphate solubilizing gene from Erwinia herbicola in two rhizobacterial strains. - Journal of Biotechnology 84: 155-161.

[40] Rosenblueth, M., Martínez-Romero, E. (2006): Bacterial endophytes and their interactions with hosts. - Molecular Plant-Microbe Interactions 19: 827-837.

[41] Sakthivel, N., Gnanamanickam, S. (1986): Toxicity of Pseudomonas fluorescens towards rice sheath-rot pathogen Acrocylindrium oryzae. - Current Science 55: 106-107.

[42] Salema, R., Brandao, I. (1973): The use of PIPES buffer in the fixation of plant cells, for electron microscopy. - Journal of Submicroscopic Cytology 5: 79-96.

[43] Scherling, C., Ulrich, K., Ewald, D., Weckwerth, W. (2009): A metabolic signature of the beneficial interaction of the endophyte Paenibacillus sp. isolate and in vitro-grown poplar plants revealed by metabolomics. - Molecular Plant-Microbe Interactions 22: 1032-1037.

[44] Schloter, M., Wiehe, W., Assmus, B., Steindl, H., Becke, H., Höflich, G., Hartmann, A. (1997): Root colonization of different plants by plant-growth-promoting Rhizobium leguminosarum bv. trifolii R39 studied with monospecific polyclonal antisera. - Applied and Environmental Microbiology 63: 2038-2046.

[45] Senthilkumar, M., Swarnalakshmi, K., Govindasamy, V., Lee, Y. K., Annapurna, K. (2009): Biocontrol potential of soybean bacterial endophytes against charcoal rot fungus, Rhizoctonia bataticola. - Current Microbiology 58: 288-293.

[46] Shahid, M., Hameed, S., Imran, A., Ali, S., van Elsas, J. D. (2012): Root colonization and growth promotion of sunflower (Helianthus annuus L.) by phosphate solubilizing 
Enterobacter sp. Fs-11. - World Journal of Microbiology and Biotechnology 28: 27492758.

[47] Shahid, M., Hameed, S., Tariq, M., Zafar, M., Ali, A., Ahmad, N. (2015): Characterization of mineral phosphate-solubilizing bacteria for enhanced sunflower growth and yield-attributing traits. - Annals of Microbiology 65: 1525-1536.

[48] Singh, B. K. (2017): Creating new business, economic growth and regional prosperity through microbiome-based products in agricultural industry. - Microbial Biotechnology 10: 224-227.

[49] Singh, R. P., Baghel, R. S., Reddy, C., Jha, B. (2015): Effect of quorum sensing signals produced by seaweed-associated bacteria on carpospore liberation from Gracilaria dura. Frontiers in Plant Sciences 6: 1-13.

[50] Somasegaran, P., Hoben, H. J. (1994): Handbook for Rhizobia: Methods in LegumeRhizobium Technology. - Springer-Verlag, Berlin.

[51] Sylvia, D. M., Fuhrmann, J. J., Hartel, P., Zuberer, D. A. (2005): Principles and Applications of Soil Microbiology. - Pearson, Prentice Hall, NJ.

[52] Thakore, Y. (2006): The biopesticide market for global agricultural use. - Industrial Biotechnology 2: 194-208.

[53] Tien, T. M., Gaskins, M. H., Hubbell, D. H. (1979): Plant growth substances produced by Azospirillum brazilense and their effect on the growth of pearl millet. - Applied and Environmental Microbiology 37: 1016-1024.

[54] Ulrich, K., Stauber, T., Ewald, D. (2008): Paenibacillus-a predominant endophytic bacterium colonising tissue cultures of woody plants. - Plant Cell, Tissue and Organ Culture 93: 347-351.

[55] Upreti, R., Thomas, P. (2015): Root-associated bacterial endophytes from Ralstonia solanacearum resistant and susceptible tomato cultivars and their pathogen antagonistic effects. - Frontiers in Microbiology 6: 1-12.

[56] Verma, S. C., Singh, A., Chowdhury, S. P., Tripathi, A. K. (2004): Endophytic colonization ability of two deep-water rice endophytes, Pantoea sp. and Ochrobactrum sp. using green fluorescent protein reporter. - Biotechnology Letters 26: 425-429.

[57] Vincent, J. M. (1970): A Manual for the Practical Study of the Root Nodule Bacteria. Burgess and Son Ltd., Westerham.

[58] Wang, K., Yan, P. S., Ding, Q. L., Wu, Q. X., Wang, Z. B., Peng, J. (2013): Diversity of culturable root-associated/endophytic bacteria and their chitinolytic and aflatoxin inhibition activity of peanut plant in China. - World Journal of Microbiology and Biotechnology 29: 1-10.

[59] Weisburg, W. G., Barns, S. M., Pelletier, D. A., Lane, D. J. (1991): 16S ribosomal DNA amplification for phylogenetic study. - Journal of Bacteriology 173: 697-703.

[60] Yaish, M. W., Antony, I., Glick, B. R. (2015): Isolation and characterization of endophytic plant growth-promoting bacteria from date palm tree (Phoenix dactylifera L.) and their potential role in salinity tolerance. - Antonie van Leeuwenhoek 107: 15191532.

[61] Yasmeen, T., Hameed, S., Tariq, M., Iqbal, J. (2012): Vigna radiata root associated mycorrhizae and their helping bacteria for improving crop productivity. - Pakistan Journal of Botany 44: 87-94.

[62] Yousaf, M., Li, J., Lu, J., Ren, T., Cong, R., Fahad, S., Li, X. (2017): Effects of fertilization on crop production and nutrient-supplying capacity under rice-oilseed rape rotation system. - Scientific Reports 7: 1270.

[63] Zakria, M., Njoloma, J., Saeki, Y., Akao, S. (2007): Colonization and nitrogen-fixing ability of Herbaspirillum sp. strain B501 gfp1 and assessment of its growth-promoting ability in cultivated rice. - Microbes and Environment 22: 197-206. 